\title{
Universiteit
}

Leiden

The Netherlands

\section{Collecting Chinese propaganda posters}

Landsberger, S.R.; Iskin, R.E.; Salsbury, B.

\section{Citation}

Landsberger, S. R. (2019). Collecting Chinese propaganda posters. In R. E. Iskin \& B. Salsbury (Eds.), Collecting prints, posters, and ephemera. Perspectives in a global world (pp. 212-227). New York: Bloomsbury Publishing. doi:10.5040/9781501338526.0020

Version:

License:

Downloaded from: $\quad$ https://hdl.handle.net/1887/3242800

Publisher's Version (Amendment Taverne) Licensed under Article 25fa Copyright Act/Law

Note: To cite this publication please use the final published version (if applicable). 


\section{Collecting Prints, Posters, and Ephemera}


Series Editor:

Kathryn Brown, Loughborough University, UK

Advisory Board:

Véronique Chagnon-Burke, Christie’s Education, USA

Christel H. Force, The Metropolitan Museum of Art, USA

Charlotte Galloway, Australian National University, Australia

Mel Jordan, Royal College of Art, UK

Alain Quemin, University of Paris 8, France

Mark Westgarth, University of Leeds, UK 


\title{
Collecting Prints, Posters, and Ephemera
}

\author{
Perspectives in a Global World
}

\author{
Edited by \\ Ruth E. Iskin and Britany Salsbury
}

B L O OMSBUR Y V IS UA L A R T S

NEW YORK • LONDON OXFORD • NEW DELHI • SYDNEY 


\author{
BLOOMSBURY VISUAL ARTS \\ Bloomsbury Publishing Inc \\ 1385 Broadway, New York, NY 10018, USA \\ 50 Bedford Square, London, WC1B 3DP, UK
}

BLOOMSBURY, BLOOMSBURY VISUAL ARTS and the Diana logo are trademarks of Bloomsbury Publishing Plc

First published in the United States of America 2019

Copyright $\odot$ Ruth E. Iskin, Britany Salsbury and Contributors, 2019

For legal purposes the Acknowledgments on $\mathrm{p}$. $\mathrm{xx}$ constitute an extension of this copyright page.

Cover design:

Cover image ()

All rights reserved. No part of this publication may be reproduced or transmitted in any form or by any means, electronic or mechanical, including photocopying, recording, or any information storage or retrieval system, without prior permission in writing from the publishers.

Bloomsbury Publishing Inc does not have any control over, or responsibility for, any third-party websites referred to or in this book. All internet addresses given in this book were correct at the time of going to press. The author and publisher regret any inconvenience caused if addresses have changed or sites have ceased to exist, but can accept no responsibility for any such changes.

Library of Congress Cataloging-in-Publication Data

TK

ISBN: HB: 978-1-5013-3-8496

ePDF: 978-1-5013-3-8519

eBook: 978-1-5013-3-8502

Series: Contextualizing Art Markets

Typeset by Deanta Global Publishing Services, Chennai, India

Printed and bound in the United States of America

To find out more about our authors and books visit www.bloomsbury.com and sign up for our newsletters.

The authors thank the Cleveland Museum of Art, especially Deputy Director and Chief

Curator Heather Lemonedes, for supporting this publication. 


\section{Contents}

List of Figures vii

Series Editor's Introduction $\quad$ xiii

Introduction Ruth E. Iskin and Britany Salsbury 1

Part I Collecting Prints $\quad 7$

Introduction, Part I: Collecting Modern and Contemporary Prints

Britany Salsbury 9

1 Henrietta Louisa Koenen's (1830-81) Amsterdam Collection of Women $\begin{array}{ll}\text { Printmakers Madeleine C. Viljoen } & 27\end{array}$

2 Loys Delteil (1869-1927): Community and Contemporary Print Collecting in Fin-de-Siècle Paris Britany Salsbury 44

3 Women Collectors of Japanese Prints: The 1909-14 Paris Expositions des estampes japonaises at the Musée des arts décoratifs Elizabeth Emery

4 Collecting Ukiyo-e Prints in Japan during the Nineteenth and Twentieth Centuries Shigeru Oikawa

5 Building Hemispheric Unity to Serve Corporate Identity: IBM's

Collection of Prints from the Americas Rachel Kaplan

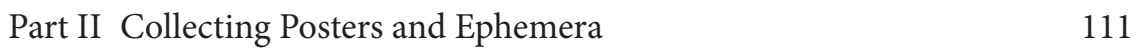

Introduction, Part II: Collecting Posters and Other Ephemera: From Modernity to the Digital Era Ruth E. Iskin

6 From Commune to Commerce: Ernest Maindron's Collecting Ephemera and Posters, Late 1850s-Early 1900s Ruth E. Iskin

7 The Maurice Rickards Collection of Ephemera Michael Twyman

8 Hans Sachs: The Most Dedicated Collector of Posters in Germany Kathleen Chapman 
9 To Possess is to Belong: Carlos Monsiváis's Collection of Ephemera and Popular Culture in Mexico City Liliana Chávez Díaz

10 The David King Collection of Russian and Soviet Ephemera at Tate: Expanding the Museum Narrative with Ephemera Sofia Gurevich

11 Collecting Chinese Propaganda Posters Stefan Landsberger

12 The Cuba Poster Project: Collecting for People, not Profit Lincoln Cushing

13 Collecting Pre- and Post-Revolution Iranian Movie Posters in the United States and in Iran Hamid Naficy

14 The Challenge of Collecting Digital Posters and Graphics from the Web: A Roundtable Discussion Anisa Hawes

Index 


\title{
Collecting Chinese Propaganda Posters
}

\author{
Stefan Landsberger
}

\section{Introduction-Chinese Propaganda Posters ${ }^{1}$}

This chapter combines two narratives. One is a brief overview of the genre of the propaganda poster and aspects of its production that are relevant for collectors. The second is my personal trajectory of more than four decades of collecting of and research on Chinese propaganda posters, which has resulted in a large private collection ${ }^{2}$ and numerous publications. ${ }^{3}$ I will look at Western and Chinese collectors of posters and their motivations for collecting from 1980 to the present. I will also discuss Chinese initiatives to create museums dedicated to Chinese posters beginning in the late 1990s, and discuss the market for posters.

More than forty years ago, in the early 1970s, I became interested in Chinese propaganda posters, not out of political sympathies, but because I wanted to study the use of art and political propaganda, and Chinese propaganda happened right before my eyes. Initially, I tried to obtain them through the People's Bookstore (Renmin Shudian) branch in Amsterdam and other shops specialized in printed materials put out by European Maoist and similar politically "progressive" fringe groups. ${ }^{4}$ By the late 1970s, I contacted the Chinese international distributor, the Guoji Shudian Company in Beijing, directly. Going to the source struck me as the best way to obtain posters. Guoji Shudian regularly sent out type-written lists of posters, on the basis of which I filed my orders. This method went smoothly until Guoji Shudian started sending materials I had not ordered, such as fairly expensive mounted scrolls of traditional ink brush reproductions. It was almost as if the Company tried to steer me into collecting more established types of Chinese art and not the posters I wanted, the ones showing excited peasants welcoming Mao Zedong, the material abundance in the people's communes, or traditionally inspired fat baby boys with gold carp or in more contemporary settings. ${ }^{5}$ I acquired the poster in Figure 11.1 from Guoji Shudian in the late 1970s and have never encountered it elsewhere (Figure 11.1).

Visual aspects of revolutionary China have appealed to Westerners from the very beginning, right from the founding of the PRC in 1949. One of the reasons was that many Westerners sympathized with the new regime. Another reason was that many saw Chinese poster art as something deliciously alien, subversive and mysterious. ${ }^{6}$ However, it was difficult to get hold of propaganda posters outside of China. Only 


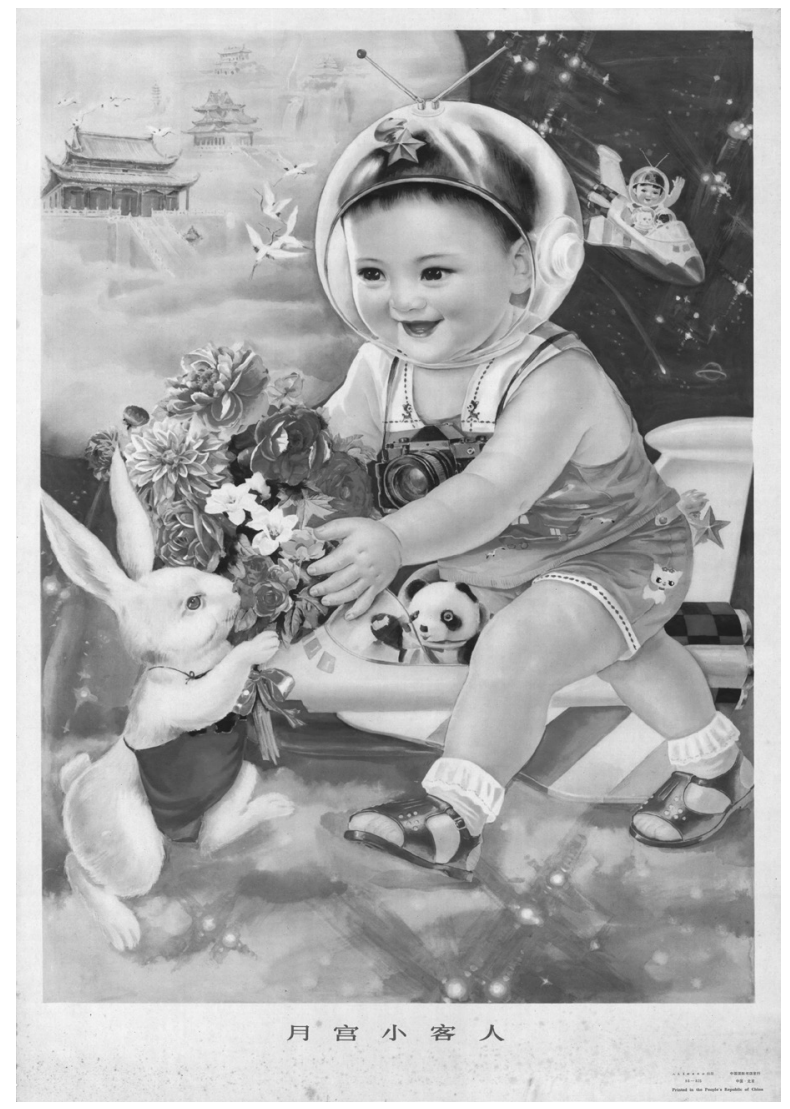

Figure 11.1 Designer unknown, Little guests in the Moon Palace (Yuegong xiao keren), published by Renmin meishu chubanshe (Beijing), c. 1972, IISH/Stefan R. Landsberger Collection, photo $\odot$ International Institute of Social History.

foreign "friends," sympathizers of the regime who had received an official invitation to visit and witness the changes the nation was going through, had the opportunity to acquire them first-hand. ${ }^{7}$ Posters served as souvenirs from revolutionary China, as opposed to the more traditional handicrafts (silks, silk screens, calligraphy scrolls, carvings, etc.) that foreign friends also brought back.

For the Chinese themselves, the propaganda poster was ubiquitous and impossible to avoid. While the propaganda wall paintings usually were only visible on the spot where they had been produced, printed posters were mass-produced and were easily and cheaply available at the Xinhua (New China) bookstores. ${ }^{8}$ Posters carried normative or political messages; they also brought some color to the places where people lived. Posters reached all levels of society: they adorned offices and factory workshops, houses, and dormitories. Schools used posters for teaching; factories, Party offices, People's Liberation Army meeting rooms, shop floors, community rooms, etc. 
all had posters on their walls; so-called mass art centers (qunzhong meishu guan), run by local cultural (Party) authorities and located in smaller urban communities and in the countryside, offered the "masses" the opportunity to learn to produce their own art and also organized poster exhibitions for workers and peasants.

Although it could be politically expedient to have a Mao poster on one's wall, as in Figure 11.2, most people liked the posters for their colors, composition, and visual contents, but turned a blind eye to their political messages. PRC posters had the same recreational functions that traditional New Year prints had had for hundreds of years in Chinese culture. These cheaply available prints, which could be calendars, traditional paintings, or simple block prints, had circulated widely long before the PRC was established. New Year prints generally portrayed events a little more beautiful than actual reality (Figure 11.2).

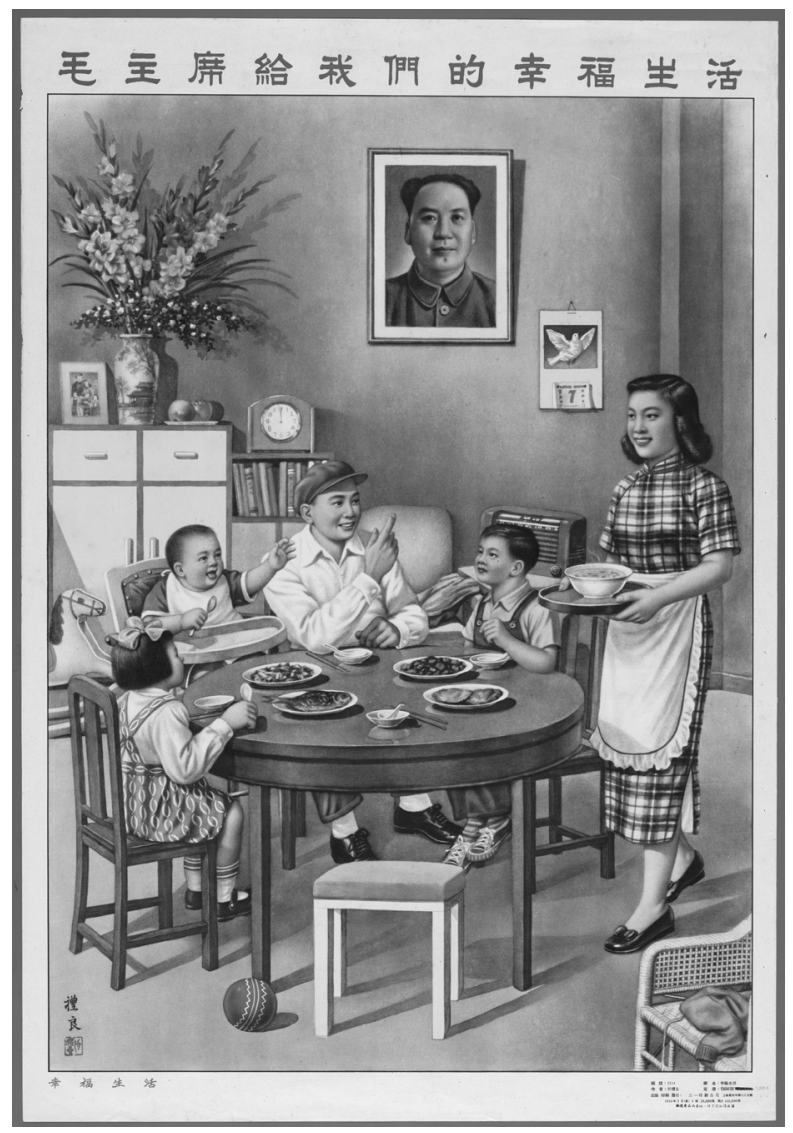

Figure 11.2 Xin Liliang, Chairman Mao gives us a happy life (Mao zhuxi gei womende xingfu shenghuo), published by Sanyi yinshua gongsi (Shanghai), March 1954, IISH/ Stefan R. Landsberger Collection, photo (c) International Institute of Social History. 


\section{Art and Propaganda Posters}

The Communist Party (CCP, established in 1921) and the PRC used posters to visualize the abstract policies and their many different grandiose visions of the future. Propaganda posters played a major role in the many campaigns that mobilized the people, and became the favored medium for educational purposes; they could easily reach the large number of illiterate Chinese in the early decades of the PRC. The government mobilized the most talented artists, many of them former commercial designers, to design the posters. Miklós Haraszti's concept of the velvet glove of political oversight over the arts is truly apt here. ${ }^{9}$

The idealized poster images did not show "life as it is," but "life as it ought to be," stressing the positive and glossing over anything negative. Newspapers, journals, and magazines reproduced original art works. These reproductions also appeared as wall paintings and as large posters in the streets, in railway stations, and in other public spaces. The smaller poster versions were distributed through the network of Xinhua bookstores; some were turned into bookmarks, appeared on biscuit tins, mirrors, cigarette packages, or matchboxes; a few even were made into postage stamps. In short, propaganda images were everywhere.

But what exactly is a Chinese propaganda poster? And is it art? None of the posters are originals; all have been mechanically reproduced. As Walter Benjamin famously argued, reproduced artwork lacks a unique presence in time and space. ${ }^{10}$ In recent years, an increasing number of the original designs (prior to being printed) for Chinese posters have resurfaced. Ha Qiongwen's and Dong Xiwen's original designs and artwork that were reproduced on numerous influential posters now are part of major Chinese museum collections in Shanghai and Beijing, respectively; ${ }^{11}$ others are in a terrible state of neglect. Reproduction, according to Benjamin, depreciates the original work, its aura and authority. One can argue that poster reproduction has made the original redundant, but the posters have another quality that Benjamin liked: their democratic potential enabled the masses to become involved in art, culture, and politics.

Although the propaganda poster dominated the political and public reality of the first three decades of the PRC, it was not a new medium. Throughout its long history, the Chinese political system has actively presented and spread its ideas of correct behavior and thought. It used paintings, songs, high- and low-brow literature, stage performances, and other artistic forms, such as New Year prints, to make sure that the cultured elite and illiterate masses behaved as they should. Once China attempted to modernize after Imperial rule ended in 1911/12, both the Nationalist Party, founded in the early 1910s, and the CCP employed visual art as a weapon to spread their messages, and gain adherents and power.

Many Chinese artists and designers insist that the term propaganda art does not apply to the contents of the posters. According to them, the visual arts consist of discrete genres, such as oil paintings, woodcuts, and propaganda posters. This classification mirrors the highly hierarchical bureaucratic framework that governs and administers the arts. Formerly, watercolorists did not mingle with oil painters, woodcutters worked 
separately from painters, and propaganda poster artists were at the bottom of the hierarchy. Chinese artists further maintain that only the use of slogans turns art into propaganda. They do not consider posters with explicit political or propagandistic contents that do not have slogans, as propaganda posters. Conversely, posters with one or more slogans, but without political or propagandistic images, qualify as propaganda in their opinion. Over the years, I have talked with many artists and designers. They acknowledged that they also had mixed up the various styles, in particular during the Great Leap Forward (1958-60) and the Cultural Revolution (1966-76), when all art had to have propaganda value and be politically inspired. But whatever goal or movement propaganda posters were designed and produced for, they had to provide information and change attitudes or even behaviors.

Themes of politics and economic reconstruction dominated posters since 1949. Most featured political obedience, and glorified work and personal sacrifice for the greater wellbeing. The images only paid attention to the personal and private dimensions of the people's lives to show how these had improved. In periods when the political grip on artistic production relaxed, posters of landscapes, historical scenes, and images from popular Beijing Opera plays were published.

\section{Collecting Posters}

After 1949, the Chinese had no private time; the government linked every activity directly to attaining its goals. Not being productive raised questions about one's political trustworthiness. Pursuing hobbies, like collecting, came in for criticism as "wallowing in petty bourgeois amusements." ${ }^{12}$ The omnipresence of the posters in public and private also held many Chinese back from collecting them, because they appeared to have no value whatsoever. This changed when the nation embraced the strategy of reform and opening up to the outside world in the early 1980s. Some Chinese started collecting "calendar girl" posters, advertising posters from the 1920s and 1930s in an Art Deco-inspired style. ${ }^{13}$ Posters from politically problematic eras however, such as the Great Leap and the Cultural Revolution, brought greater political risks to the collectors; the leadership was still debating the official verdict on these events. Collecting such materials could bring political trouble to the collector.

Once China freely allowed visitors from the West in the late 1970s, collecting became easier. I and other Western poster collectors merely needed to find the nearest local Xinhua bookshop in every city or town we went to. ${ }^{14}$ Each Xinhua bookshop had a poster section, with the available posters on display. When I went into a Xinhua bookshop during my first visit to China in 1980, it was like entering Poster Heaven. Shop assistants and curious onlookers peppered me with questions: "Why are you buying propaganda posters?" "Why do you like them?" "Why don't you rather buy the 'real' art that other foreigners buy?" By "real art" they referred to (reproductions of) traditional Chinese painting, stone rubbings, calligraphy, etc. They refused to believe that I wanted to use the posters for research purposes: "Nobody in China is interested 
in these things, so why would you study them," etc. Some shop assistants refused to sell posters, whereas others went out of their way to help. In 1987, in a small Xinhua store in Qufu, Shandong Province, now a major tourist destination, the section head started to take posters off the wall, as the posters in stock had been sold out. If I did not mind the holes left by the thumbtacks, I could have them; I bought them, of course.

One can still buy such posters from the past, but no longer at the Xinhua bookstores. The highest levels of officials in the propaganda system decided, probably around the mid-1990s, to stop producing propaganda posters for sale. Presently, propaganda is distributed through other media such as popular music, films, computer games, television, and the internet. The posters have been relegated to open antique markets such as Baoguosi and Panjiayuan, ${ }^{15}$ both in Beijing, where collectors, foreign and Chinese, young and old, converge during the weekends. Indeed, most Chinese collect something these days, and growing numbers of them are interested in posters, rationing coupons, Mao buttons, Red Guard uniforms, and other objects, mostly because of their potential future value. A considerable number of private sellers, often collectors themselves, have emerged as the most valuable source for buying posters. The internet also is now a major source for acquiring posters. A number of Chinese and Western sites specialize in posters. Although it is risky to ascertain the authenticity and quality of posters on the basis of a digital scan, when one's relationship with the seller is good, one usually can trust the latter's judgment about authenticity.

\section{Collecting Chinese Posters Today: Issues and Methods}

The sustained use of posters for mass campaigns suggests that they were produced in massive numbers. Up until now, I have not been able to establish which publisher published which posters in what quantities. There is no central, comprehensive catalogue covering all poster publications since 1949. Although the National Library of China in Beijing has served as a "legal deposit" authority (and continues to do so) to which all publishers have to present a copy of their productions, the Library's poster section is in disarray and not well-looked after. ${ }^{16}$ The Library lacks the official and political support, funding, and the motivation to make this treasure trove accessible in any form.

In January of 1998, I visited the major publishing houses in Beijing and Shanghai. ${ }^{17}$ In interviews with their representatives, many stressed that they had no records of past poster publishing activities and that archives or samples of these activities did not exist. If the publishers themselves did not, or no longer, maintain records of the posters they produced, we need to turn to alternative sources for information. In the 1950s and early 1960s, poster publishers sent out illustrated brochures of their planned production to the Xinhua bookshops that sold posters. Such brochures can help to reconstruct the poster production of a single publisher. However, this does not tell us how widely available posters were. Did the publishers in Beijing and Shanghai monopolize the market, or did the Hunan, Liaoning, or Shaanxi publishers have a share, too? Given the problems of infrastructure and distribution that plagued China in the 1950s and later, 
one must assume that local production determined the availability of posters. In the early years of the Cultural Revolution (1966-69) for example, poster production was almost completely decentralized to the provincial, municipal, or lower-level publishers. Moreover, Red Guard factions all over the country published their own posters, often in a much sought-after, simple, red-black-white color scheme that resembled the block prints produced in the late 1930s-early 1940s, as in Figure 11.3. Even for these seemingly "spontaneous," "locally produced" posters, the central levels often provided the originals ${ }^{18}$ (Figure 11.3).

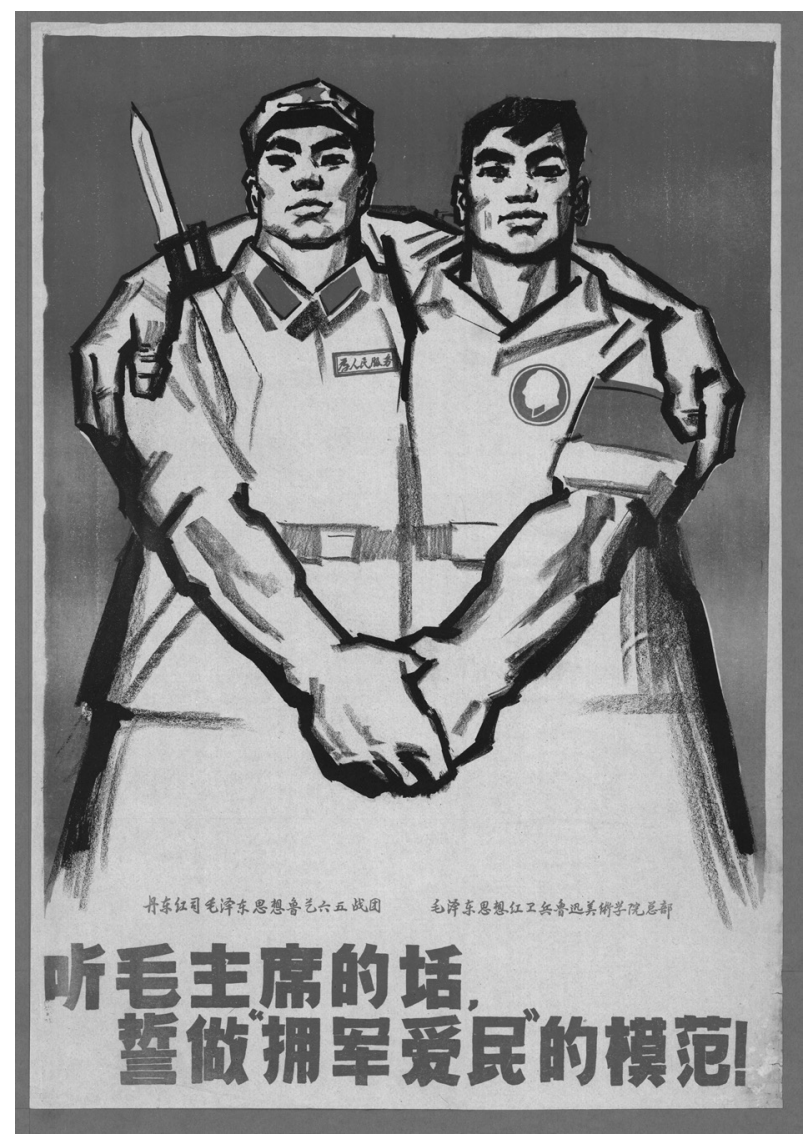

Figure 11.3 Dandong Red Headquarters of the Lu Xun Art Academy Mao Zedong Thought 65th Battalion, General Department of the Lu Xun Art Academy Mao Zedong Thought Red Guards, Listen to the words of Chairman Mao, swear to follow the model of "Support the army, love the people"! (Ting Mao zhuxi de hua, shizuo "yongjun aimin" de mofan!), publisher unknown, c. 1968, IISH/Stefan R. Landsberger Collection, photo () International Institute of Social History. 


\section{Collecting Posters: Scope of Publication Numbers}

Although we do not know how many posters were published, we can estimate on the basis of incomplete statistics. The journal Renmin meishu (People's Art) calculated in April 1950 that in the year 1949, 379 different poster designs were published nationwide, with a total print run of almost 6.8 million copies. Some 10 percent of them featured the founding of the PRC, and 13 percent showed the deep love of the people for the new leadership. Another 10 percent illustrated the close relations between the Army and the people, and 31 percent of them dealt with agricultural production. ${ }^{19}$ The scholar Kuiyi Shen ${ }^{20}$ has calculated that the Shanghai People's Fine Arts Publishing House published more than 2,000 poster designs in 40 million copies between 1954 and 1966, whereas the Beijing People's Fine Arts Publishing House published 500 poster designs in some 28 million copies between 1951 and 1959. ${ }^{21}$ Aside from these incomplete figures, many individual posters provide some information in the imprint in the lower right hand corner. These imprints give details about the publisher, printer, size of the poster, print number, number of editions, and the size of the print runs.

\section{Collections and Museums in the West}

One can classify the collections of Chinese propaganda posters, both in China and the West, as either private or institutional. In recent times, the advent of the internet has made these collections much more visible and accessible. In some Western collections, the Chinese poster holdings form part of a much broader collection, enabling a comparative study of, for example, the development of graphic design. The Swiss collector René Wanner is a representative of this group of collectors of graphic design, and there are many others. ${ }^{22}$

Many Western private collectors spent time in or close to China. After their retirement or death, they often donated their collections to (academic) institutions or libraries to allow their use as research materials. The personal archives of the missionaries who worked in China in the late 1800s-early 1900s, for example, are important sources for late Imperial and Republican posters. Haverford College (Haverford, Pennsylvania, United States) has some spectacular anti-communist and anti-Japanese posters collected and later bequeathed by Dr. William W. Cadbury and his spouse Catherine J. Cadbury, Quakers who worked as medical missionaries in Southern China in the 1900s-40s. ${ }^{23}$

The late Professor Jon Sigurdson donated his superb collection of some 1,200 posters, acquired in China in the period 1962-83, to a Swedish institute of higher learning. ${ }^{24}$ Ann Tompkins ${ }^{25}$ went to China on invitation in 1965 and lived and worked there for five years. The posters she bought and collected during her sojourn in China, now named the Ann Tompkins (Tang Fandi) and Lincoln Cushing Chinese Poster Collection, were donated to the UC Berkeley's East Asian Library and the Center for the Study of Political Graphics. ${ }^{26}$ The British journalist and China expert John Gittings 
started collecting propaganda posters and Chinese daily necessities while stationed in Hong Kong in the 1960s and 1970s. ${ }^{27}$ His vision was to establish the Chinese Visual Arts Project, a collection of artifacts that made daily life in China visible and tangible for Western students. He founded the China Poster Collection at the University of Westminster, London, in 1977, with some 800 posters from the late 1950s up to the early 1980s. ${ }^{28}$ The British Museum and the British Library, ${ }^{29}$ both in London, have received or acquired significant posters over the years, as has the Library of Congress in Washington DC. In 2009, the latter discovered a hitherto unknown collection of some 6,000 items related to the Sino-Japanese War (1937-45). ${ }^{30}$

My own collection, the IISH/Stefan R. Landsberger Collection, currently numbers some 6,000 items, spanning the period 1937 to the present. Together with the Chinese poster holdings of the International Institute of Social History, Amsterdam, and the

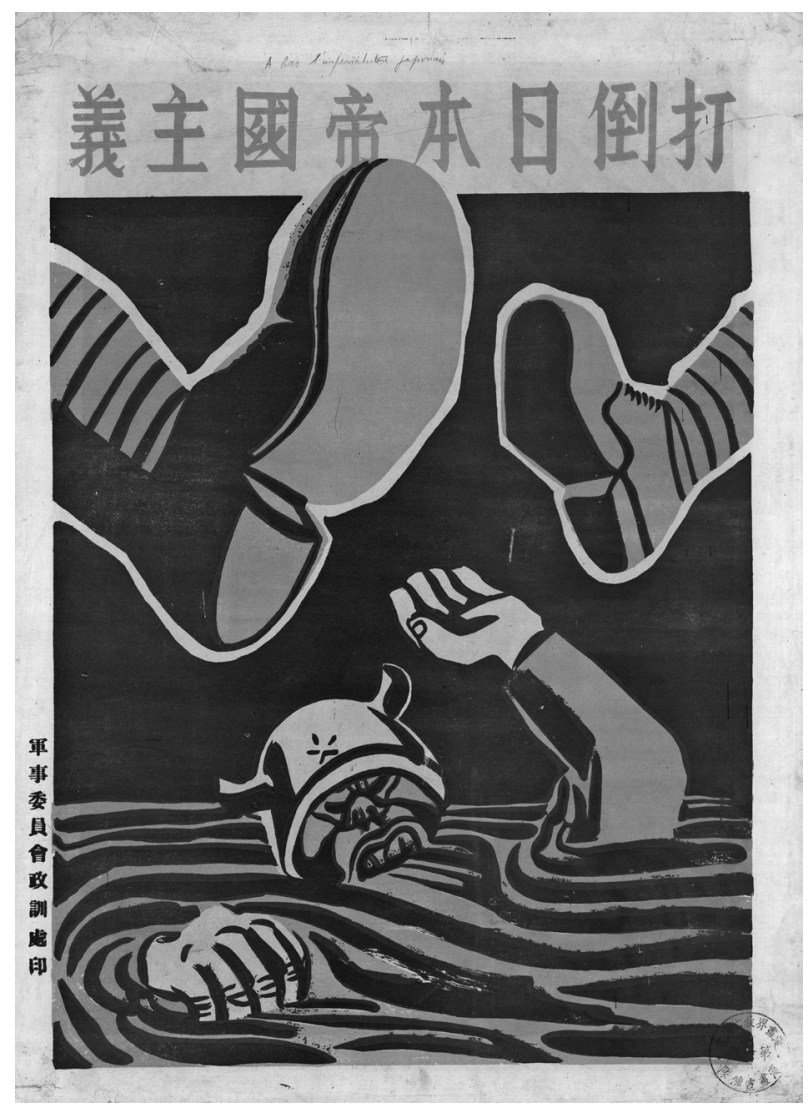

Figure 11.4 Designer unknown, Defeat Japanese imperialism (Dadao Riben diguozhuyi), published by Junshi weiyuanhui zhengxunchu, c. 1937, IISH/Stefan R. Landsberger Collection, photo (C) International Institute of Social History. 
collection of an unnamed private collector in Amsterdam, the Landsberger Collection forms one of the most comprehensive ones in the world, totaling more than 10,000 items. Some 1,500 posters from these combined collections are accessible online, with information about the images, date of production and the designers. ${ }^{31}$ A large selection of images from these three collections is also available elsewhere online. ${ }^{32}$ These two sites aim to make as many high-quality scans of Chinese propaganda posters as possible available in the public domain. The three collections collaborate in the Chinese Posters Foundation and are still expanding.

I estimate that I picked up 30-40 percent of my collection from the Xinhua bookstores in the period 1980-95. Later additions largely came from private sources. After my first book on the subject appeared in $1995,{ }^{33}$ the circles of collectors that emerged in China in the 1990s classified me as a collector and not a dealer; this enabled me to develop relations with many Chinese collectors all of over China. Other sources from which I acquired posters ranged from Hong Kong collectors and sellers to archives of Friendship Associations in Europe, auctions, etc. Presently, my collecting activities mostly take place over the internet and by going to China, to maintain contacts and scour antique markets. My earliest posters date from 1937, a series devoted to the Anti-Japanese War which I acquired outside China (Figure 11.4). My most recent ones are posters from 2015, published for official use on the occasion of the Seventieth Anniversary of the Victory of the Chinese Anti-Japanese War and the Global War Against Fascism that was marked with a military parade in Beijing in August 2015.

\section{Collections and Museums in China}

The focus of Chinese collectors often differs from that of Western collectors. A great number of the former are mainly interested in collecting Mao images. Only in recent years have Cultural Revolution posters increasingly drawn the attention of Chinese collectors. When identifying representatives of the Chinese collectors' field, some names immediately spring to mind, because their early online presence and other activities have put their collections in the spotlight. But there are many others.

Yang Peiming was one of the first Chinese collectors to start exhibiting his collection. He has become renowned among many as the proprietor of the Shanghai Propaganda Poster Art Center in Shanghai. ${ }^{34}$ Yang started collecting posters in 1995 when government organizations started destroying propaganda materials out of political expediency. He established a physical museum in a single room in 2002; this has gradually developed into a three-room establishment totaling 400 square meters, housing thousands of posters. In March 2012, the museum obtained an official license from the Shanghai municipal government as a private museum; being private instead of official allows Yang the necessary leeway to operate. Yang has a collection of over 6,000 Chinese propaganda posters from 1940 to 1990, with a large number of Cultural Revolution posters; he has an additional collection of hundreds of original Shanghai “calendar girl" posters from 1910 to 1940 . Yang also sells high-quality posters. 
A specialized collector is Beijing-based Guo Lei. A staff member of the Olympic Affairs Committee under the Ministry of Sports, as well as secretary of the Sports Committee of the Chinese Association of Collectors and editor in chief of the journal Chinese Sports Collecting, Guo focuses on sports-related propaganda in all its forms. He also maintains a website that highlights his spectacular private collection of sports posters and paraphernalia. ${ }^{35}$ In 2012, he showcased his collection in Inspire China: New China Sports Posters (1952-2012), published with the Beijing-based Contemporary China Publishing House.

Dong Zhongchao, also from Beijing, is the last private collector I want to mention. He was one of the first to move beyond selling posters (initially at the famous antique outlet Curio City, next to Panjiayuan) into related fields. His poster collection numbers some 6,000 examples, some of which appeared in his book Hong hua - Red pictores 1966-1978 (sic) (Hong Kong: Zhongguo guoji tushu chubanshe, 2011). Dong has become increasingly interested in collecting the artifacts and props that appear in the posters he has collected. These range from thermos flasks, alarm clocks, and aluminum tea mugs to travel bags and children's toys. ${ }^{36}$ Dong has become involved in the management and organizational aspects of collecting. As one of the Vice-Secretaries of the nationally approved Association of Red Collectors under the Chinese National Association of Collectors, he plays a major role in articulating collectors' interests and in organizing exhibition activities. The most recent one was an exhibition to mark the ninetieth anniversary of the founding of the People's Liberation Army, which was held at the Urban Planning Museum in Chaoyang District, Beijing, in August 2017. The compilation of Red Collection Exhibition Halls, Museums and Private Exhibition Venues, the first comprehensive overview of Chinese collections that are on display in one form or another published in September 2017, is another milestone of the Red Collectors Association.

One of the destinations where some of the posters and objects that Dong Zhongchao has collected over the years end up is the Jianchuan Museum Cluster in Anren Town, Sichuan province. ${ }^{37}$ Where Yang Peiming tries to run a museum under the watchful eyes of the Shanghai municipal government, the former property developer and real estate mogul Fan Jianchuan has so much local clout and influence that he has been able to build a complete 100,000 square meter "museum settlement." Yet, it is still a private museum, which has to navigate both local politics and national censors. With thirty buildings planned, eighteen are in operation at present; thirteen of these display materials and provide information on the Anti-Japanese War, the Wenchuan earthquake (2008), and the Cultural Revolution. Fan's overriding aim is to present the true history of China of the last 100 years. Of particular interest for this chapter are the five so-called Red Age (i.e., the Mao era) ${ }^{38}$ Museums, devoted to porcelains; daily necessities; Mao badges, table clocks and official seals; mirrors; and educated youths.

Fan Jianchuan is one of the most important and voracious Chinese collectors at the moment. Quoting Denise Ho and Jie Li, as a boy he "began collecting things related to the Cultural Revolution-Mao badges, Red Guard armbands, and various flyers and pamphlets-eventually amassing an astounding collection of millions of 'red artifacts." ${ }^{39} \mathrm{He}$ allegedly has brought together "30 tons of handwritten materials, 
20,000 diaries, a hundred thousand propaganda posters, and millions of Mao badges"; some of them are already on display, some still await an appropriate location. ${ }^{40}$

The newly established M+ Museum for visual culture, focusing on twentieth- and twenty-first-century art, design, architecture, and moving images, fairly recently emerged as a collecting unit. ${ }^{41}$ Located in the West Kowloon Cultural District in the Hong Kong Special Administrative Zone and scheduled to open officially in 2019, M+ aims "to become the hub for Chinese propaganda posters in Asia, while presenting an alternative perspective of contextualizing them with contemporaneous materials from other disciplines such as visual art, product design, graphic design, comics, and publications." ${ }^{22}$ In its M+ Pavilion, the first exhibition space of the complex to start operation, $\mathrm{M}+$ presented some of the posters it had acquired in the "Collectivisation: China under Mao" section of Shifting Objectives: Design from the M+Collection, a show that ran from the November 30, 2016, to February 5, 2017.43

\section{Collecting Posters: The Market}

The increased demand for posters has driven up prices in the past ten years, while the number of interesting posters on offer has decreased dramatically. The posters one could pick up in the 1980s for only two mao (approx. €0.03 in May 2017 prices) now fetch up to 2,000 yuan or more ( $€ 265$ based on May 2017 prices). On many urban street corners, cheap fake posters, mainly recent reprints are on offer. For those not in the know, and even for those who are, with ever improving printing and copying techniques and facilities, it has become increasingly difficult to distinguish the real from the fake.

With more Chinese collectors active, including major ones like Fan Jianchuan and the M+ Museum, the poster market in China is getting tighter. Chinese collectors have an advantage over non-Chinese collectors because they speak the language, know the culture, and often have extensive contacts or networks sourcing interesting materials for them. While the widespread use of the internet has made it easier for Western collectors to identify and communicate with potential Chinese poster sellers, it has also made collecting more complicated. It is difficult to establish the authenticity of posters offered on the internet, and shipping them, clearing (Chinese and Western) customs, payments, etc. can also pose problems.

Many members of the Red Collectors group under the Chinese Association of Collectors are active in one or more informal internet chat groups. Using the WeChat (WeiXin) app for instant messaging, commerce, and payment services, developed by the Tencent Company and first released in $2011,{ }^{44}$ they communicate freely, refer each other to interesting opportunities, enquire about rare editions, discuss pricing strategies, etc. Many of them are nostalgic about the past, in particular about Mao Zedong and the Cultural Revolution. The increasingly nationalistic and patriotic tone of the communications in some groups has puzzled me. Japan and the United States, and more recently South Korea, serve as the usual targets of their vitriol and hatred. But a hostile attitude has developed 
toward foreign collectors as well. In some online exchanges, sellers express alarm about posters that they consider important ending up in the hands of foreigners; in their reasoning, such posters should remain in China as they are the property of the Chinese people. They call upon each other to refrain from selling to Westerners.

It should also be noted that the market for posters exists in China only, even though Western collectors participate in it. Incidental Western auctions aside, the market for posters outside of China is very small. There is no set price for a poster and the pricing policies and strategies are opaque: one seller may sell a poster for a lower price than another; today's price may be higher than yesterday's; buying in quantity may get one a better price; a Chinese customer may pay a lower price than a foreign one, etc. The absence of an objective, binding pricing system makes poster appraisal extremely difficult.

Despite rising prices and dwindling supplies, every time I go to China I encounter posters I did not know existed beforehand-posters that I am desperate to add to my collection. I know that other collectors have the same experience. The chance to stumble upon an unexpected find, to haggle for a better price, to scour marketsall these aspects urge me on in my quest to bring together the most comprehensive Chinese poster collection possible. Over the years, collecting Chinese posters has become easier and at the same time more complicated, but it is one of the most fulfilling activities I can imagine.

\section{Notes}

1 This chapter has benefited enormously from the decades' long cooperation, discussions, and talks with Mr. Marien van der Heijden, International Institute of Social History, Amsterdam.

2 Parts of this collection are available on https://chineseposters.net/ and https://www.fli ckr.com/photos/chinesepostersnet/

3 Stefan R. Landsberger, Chinese Propaganda Posters - From Revolution to Modernization (Amsterdam, Singapore/Armonk: The Pepin Press/M.E. Sharpe 1995, 1998/1996); Landsberger, "Contextualising (Propaganda) Posters," in Visualising China, 1845-1965: Moving and Still Images in Historical Narratives, ed. Christian Henriot and Wen-hsin Yeh (Leiden: Brill, 2013), 379-405; Landsberger, Marien van der Heijden, and Shen Kuiyi, Chinese Posters - The IISH/Landsberger Collections (München: Prestel Verlag, 2009); Landsberger, "The Deification of Mao: Religious Imagery and Practices during the Cultural Revolution and Beyond," in China's Great Proletarian Cultural Revolution: Master Narratives and Post-Mao Counternarratives, ed. Woei Lien Chong (Lanham, MD: Rowman \& Littlefield Publishers, 2002).

4 The People's Bookstores (Renmin Shudian) were foreign branches of the Xinhua (New China) bookstore company.

5 This section is based on Landsberger, "Confessions of a Poster Collector," China Information Anniversary Supplement (Summer 1994), 37.

6 Landsberger, “Revolutionärer Kitsch': Das Beispiel China," in Kitsch und Nation - Zur kulturellen Modellierung eines polemischen Begriffs, eds. Kathrin Ackermann and Christopher F. Laferl (Bielefeld: transcript Verlag, 2016), 248. 
7 For example, Gerhard Pommeranz-Liedtke, in charge of art publications and exhibitions at the state-run Academy of the Arts in Berlin (East), who visited China three times in the period 1953-8. Patrizia Jirka-Schmitz, Chinese Vintage Posters from the Collection of G. Pommeranz-Liedtke (Cologne: Lempertz Auction 981, 2011), 4.

8 Lincoln Cushing and Ann Tompkins, Chinese Posters-Art from the Great Proletarian Cultural Revolution (San Francisco: Chronicle Books LLC, 2007), 24.

9 Miklós Haraszti, The Velvet Prison; Artists under State Socialism (New York: Basic Books, 1987), 129-41.

10 Walter Benjamin, "The Work of Art in the Age of Mechanical Reproduction" (1936), http://www.marxists.org/reference/subject/philosophy/works/ge/benjamin.htm.

11 For Ha Qiongwen, see: https://chineseposters.net/artists/haqiongwen.php; for Dong Xiwen, see: https://chineseposters.net/artists/dongxiwen.php.

12 Shaoguang Wang, "The Politics of Private Time: Changing Leisure Patterns in Urban China," in Urban Spaces in Contemporary China-The Potential for Autonomy and Community in Post-Mao China, ed. Deborah S. Davis, Richard Kraus, Barry Naughton, and Elizabeth J. Perry (Cambridge: Cambridge University Press, 1995), 155.

13 See Ellen Johnston Laing, Selling Happiness-Calendar Posters and Visual Culture in Early-Twentieth-Century Shanghai (Honolulu: University of Hawaii Press, 2004).

14 Landsberger, "Confessions," 38.

15 Many sellers have a small shop on the second floor of the Modern Collection Area at Panjiayuan. The "Red" collectibles are presented here: http://www.panjiayuan.com/ hc.

16 Based on talks with representatives of the Poster Department of the National Library in Beijing in 2013 and 2015.

17 The People's Publishing House, People's Fine Arts Publishing House, People’s Sports Publishing House, People's Educational Publishing House (Beijing), Shanghai People's Publishing House and Shanghai's People's Fine Arts Publishing House (Shanghai).

18 Geming da pipan baotou xuanji (A Selection of Revolutionary Great Criticism Mastheads) (Hangzhou: Zhejiang renmin meishu chubanshe, 1970).

19 Jian An, "Yijiuwuling nian nianhua gongzuode jixiang tongii" (Some Statistics on New Year Print Production in 1950), Renmin meishu 2 (April 1950): 52-3.

20 Kuiyi Shen, Professor of Asian Art History, Theory, and Criticism at the University of California, San Diego, is an expert on twentieth-century Chinese art, contemporary Chinese art and mass culture.

21 Kuiyi Shen, "Propaganda Posters and Art during the Cultural Revolution," in Art and China's Revolution, ed. Melissa Chiu and Zheng Shengtian (New Haven: Yale University Press, 2009), 156.

$22 \mathrm{http} / / / \mathrm{www} \cdot$ posterpage.ch/.

23 See https://www.haverford.edu/east-asian-languages-and-culture/news/workshop-ha verfords-chinese-propaganda-poster-collection and http://library.haverford.edu/file-i d-910.

24 http://chinaposters.org/front/front.

25 Ann Tompkins, a social worker, attended the 1965 World Peace Congress in Helsinki. She was invited to China in 1965 and worked as an English language instructor at the Beijing Foreign Languages Institute for five years. 
26 Cushing and Tompkins, Chinese Posters. http://www.docspopuli.org/ChinaPosters.h tml.

27 http://www.johngittings.com/.

$28 \mathrm{http}: / /$ chinaposters.westminster.ac.uk/zenphoto/page/about.

29 https://www.bl.uk/collection-guides/chinese-propaganda-posters.

30 https://blogs.loc.gov/international-collections/2016/09/posters-on-the-sino-japanesewar-of-1937-45-at-the-asian-division-library-of-congress/.

31 https://chineseposters.net/.

32 https://www.flickr.com/photos/chinesepostersnet/.

33 Landsberger, Chinese Propaganda Posters (1995).

34 The Museum site is at http://www.shanghaipropagandaart.com/about.asp. See also Borders of Adventure, "The Shanghai Propaganda Poster Art Centre-The Director's Cut" (https://www.bordersofadventure.com/shanghai-propaganda-poster-art-cen tre/); Wikipedia (https://en.wikipedia.org/wiki/Propaganda_Poster_Art_Centre) ; and TripAdvisor (https://www.tripadvisor.com/Attraction_Review-g308272-d1887 174-Reviews-Shanghai_Propaganda_Poster_Art_Centre-Shanghai.html).

35 http://www.gc1999.com. The site of the Sport Collectors Association is at http:// www.ticang.com.

36 Emily Williams, "Collecting the Red Era in Contemporary China," Made in China 2, no. 3 (2017): 81-2.

37 The Museum site is at http://www.jc-museum.cn/en/.

38 Denise Y. Ho and Jie Li, "From Landlord Manor to Red Memorabilia: Reincarnations of a Chinese Museum Town," Modern China 42, no. 1 (2016): 27.

39 Ho and Li, "From Landlord Manor," 26.

40 Ibid.

41 The Museum site is at https://www.westkowloon.hk/en/mplus.

42 Personal briefing by M+ curator Pi Li and others in Beijing, May 25, 2017.

43 https://www.westkowloon.hk/en/shiftingobjectives/exhibition-trailer.

44 https://en.wikipedia.org/wiki/WeChat.

\section{Selected Bibliography}

Chiu, Melissa and Zheng Shengtian, eds. Art and China's Revolution. Asia Society/Yale University Press, 2009.

Cultural Revolution and Beyond, Chinese Propaganda Posters-From Revolution to Modernization. Amsterdam, Singapore/Armonk: The Pepin Press/M.E. Sharpe 1995, 1998/1996.

Cushing, Lincoln and Ann Tompkins. Chinese Posters - Art from the Great Proletarian Cultural Revolution. San Francisco: Chronicle Books LLC, 2007.

Ho, Denise Y. and Jie Li. "From Landlord Manor to Red Memorabilia: Reincarnations of a Chinese Museum Town." Modern China 42, no. 1 (2016): 3-37.

Laing, Ellen Johnston. Selling Happiness - Calendar Posters and Visual Culture in EarlyTwentieth-Century Shanghai. Honolulu: University of Hawai'i Press, 2004.

Landsberger, Stefan R. “Contextualising (Propaganda) Posters." In Visualising China, 1845-1965: Moving and Still Images in Historical Narratives, edited by Christian Henriot and Wen-hsin Yeh, 379-405. Leiden: Brill, 2013. 
Landsberger, Stefan R. “The Deification of Mao: Religious Imagery and Practices during the Cultural Revolution and Beyond." In China's Great Proletarian Cultural Revolution: Master Narratives and Post-Mao Counternarratives, edited by Woei Lien Chong, 139-84. Lanham, MD: Rowman \& Littlefield Publishers, Inc., 2002.

Landsberger, Stefan R., Marien van der Heijden, and Shen Kuiyi. Chinese Posters - The IISH/Landsberger Collections. Munich: Prestel Verlag, 2009.

Williams, Emily. "Collecting the Red Era in Contemporary China." Made in China 2, no. 3 (2017): 78-83. 